\title{
Field and laboratory metabolism and thermoregulation in rhinoceros auklets
}

\author{
Aika Umeyama ${ }^{1}$, Yasuaki Niizuma ${ }^{\text {Corresp., } 1}$, Masaki Shirai ${ }^{2}$ \\ ${ }^{1}$ Laboratory of Environmental Zoology, Faculty of Agriculture, Meijo University, Nagoya, Aichi, Japan \\ 2 Environmental Science Research Laboratory, Central Research Institute of Electric Power Industry, Abiko, Chiba, Japan \\ Corresponding Author: Yasuaki Niizuma \\ Email address: niizuma@meijo-u.ac.jp
}

Seabirds spend most of their lives at sea, except when visiting their breeding sites. Since the thermal conductivity of water is 25 times higher than that of air, seabirds resting on water lose heat and expend a considerable amount of energy for thermoregulation. For example, rhinoceros auklet (Cerorhinca monocerata), a medium-sized (480-620 g) alcid, spends most of its time floating on the sea. In order to estimate the cost of this behavior in terms of their daily energy expenditure (DEE), we studied rhinoceros auklets breeding on Teuri Island, Hokkaido Japan. We measured their resting metabolic rate (RMR) in air and on water by respirometry, and estimated their DEE by the doubly labeled water method. While RMR on water did not vary significantly between $10^{\circ} \mathrm{C}$ and $15^{\circ} \mathrm{C}$, it was significantly higher at $5^{\circ} \mathrm{C}$. Air temperature $\left(5.0-20.0^{\circ} \mathrm{C}\right)$ had no effect on RMR. The DEE of freeranging auklets averaged $1005.5 \mathrm{kJday}^{-1}( \pm 130.2, \mathrm{n}=3$ ). Our results indicate that RMRs are elevated for auklets resting on water, particularly below their lower critical temperature (LCT), compared with in air. Accordingly, spending time above their LCT on water at any time of year will provide enhanced benefits, particularly to seabirds such as rhinoceros auklets which rest a considerable amount of time on water. 


\section{Field and laboratory metabolism and thermoregulation in}

\section{2 rhinoceros auklets}

3

4

5

6

10

11

12

Aika Umeyama ${ }^{1}$, Yasuaki Niizuma ${ }^{1}$ and Masaki Shirai ${ }^{2}$

${ }^{1}$ Laboratory of Environmental Zoology, Faculty of Agriculture, Meijo University, Shiogamaguchi 1-501, Tenpaku-ku, Nagoya 468-8502, Japan

2 Environmental Science Research Laboratory, Central Research Institute of Electric Power Industry, 1646 Abiko, Abiko, Chiba 270-1194, Japan

Corresponding Author:

Yasuaki Niizuma

Laboratory of Environmental Zoology, Faculty of Agriculture, Meijo University, Shiogamaguchi 1-501, Tenpaku-ku, Nagoya 468-8502, Japan

Email address:niizuma@meijo-u.ac.jp

\section{Abstract}

Seabirds spend most of their lives at sea, except when visiting their breeding sites. Since the thermal conductivity of water is 25 times higher than that of air, seabirds resting on water lose heat and expend a considerable amount of energy for thermoregulation. For example, the rhinoceros auklet (Cerorhinca monocerata), a medium-sized $(480-620 \mathrm{~g})$ alcid, spends most of its time floating on the sea. In order to estimate the cost of this behavior in terms of their daily energy expenditure (DEE), we studied rhinoceros auklets breeding on Teuri Island, Hokkaido Japan. We measured their resting metabolic rate (RMR) in air and on water by respirometry and estimated their DEE by the doubly labeled water method. While RMR on water did not vary significantly between $10^{\circ} \mathrm{C}$ and $15^{\circ} \mathrm{C}$, it was significantly higher at $5^{\circ} \mathrm{C}$. Air temperature $\left(5.0-20.0^{\circ} \mathrm{C}\right)$ had no effect on RMR. The DEE of free-ranging auklets averaged 1005.5 kJday-1 $( \pm 130.2, n=3)$. Our results indicate that RMRs are elevated for auklets resting on water, particularly below their lower critical temperature (LCT), compared with in air. Accordingly, spending time above their LCT on water at any time of year will provide enhanced benefits, particularly to seabirds such as rhinoceros auklets which rest a considerable amount of time on water.

\section{Introduction}

The ability of endothermic animals to thermoregulate may affect their life history traits, foraging behavior, and their distributions (Jenssen, Ekker \& Bech, 1989; Humphreys, Wanless \& Bryant, 2006; Lovvorn et al., 2009). Endothermic animals living in or on the sea expend considerable energy on thermoregulation even while resting on the surface because the thermal conductivity of water is 25 times great than that of air (Kaseloo \& Lovvorn, 2005; Niizuma et al., 2007). Biologging techniques have shown that adult seabirds spend significant amounts of time resting on the sea during their chick-rearing period (Wilson, Weimerskirch \& Lys, 1995; Garthe, Grémillet \& Furness, 1999; Falk et al., 2000; Daunt et al., 2002; Tremblay et al., 2003; Kato, Watanuki \&

PeerJ reviewing PDF | (2020:09:52974:4:0:NEW 23 Apr 2021) 
42 Naito, 2003). In addition to measurements of the high cost behaviors such as flying and diving

43 (Elliott et al., 2013a), it is important to assess their energy expenditure during resting in order to

44 more fully understand their energetics.

Seabirds may have physiological adaptations for floating on cold sea water, which include reducing their thermal conductance by means of a thick water-repellent plumage (Kooyman et al., 1976; Jenssen, Ekker \& Bech, 1989; Dawson et al., 1999) and reducing heat flow to the periphery via vasoconstriction in the skin and appendages (Johansen \& Bech, 1983; Folkow \& Blix, 1987; Niizuma et al., 2007). The air trapped in the loose tangle of air pockets formed by the barbs and barbules of their plumulaceous inner vanes is the main component of plumage insulation for seabirds (Dawson et al., 1999). However, this insulation may constrain their rate of heat dissipation while flying between their nesting and foraging areas because birds produce excess heat during energy-intensive flapping flight (Elliott et al., 2013a; Guillemette et al., 2016; Nord \& Nilsson, 2019). This may be especially significant in the temperate zone, where seabirds are less able to lose heat in the mild climate, yet endothermic animals must dissipate their metabolic heat to avoid reaching lethal body temperatures (Speakman \& Król, 2010; Nilsson, Molokwu \& Olsson, 2016).

The Alcidae, a group of seabirds that breed from the temperate zone to the Arctic, have relatively dense plumage, high wing loading and continuous fast flapping flight, deliver food to their nestlings during the chick-rearing period, but spend significant amounts of time resting on the sea (Wilson, Weimerskirch \& Lys, 1995; Gaston \& Jones, 1998; Garthe, Grémillet \& Furness, 1999; Falk et al., 2000; Daunt et al., 2002; Tremblay et al., 2003; Kato, Watanuki \& Naito, 2003). The rhinoceros auklet (Cerorhinca monocerata), a medium sized (480-620 g) member of the Alcidae, breeds on offshore islands in areas of temperate waters in the northern Pacific and migrates southward to wintering areas (Gaston \& Jones, 1998). The auklets rearing chicks on Teuri Island, Hokkaido, Japan, spend $18 \%$ of their time on land at the colony, $14 \%$ flying, $13 \%$ in diving related behavior, but 55\% floating on the sea (Kato, Watanuki \& Naito, 2003). During their annual movement, they experience various water temperatures ranging from cold $\left(4-6^{\circ} \mathrm{C}\right)$ in early March, associated with their northward migration and early arrival on the breeding grounds, to mild $\left(11-14^{\circ} \mathrm{C}\right)$ during the winter from October to late February in the southwestern Sea of Japan Sea (Takahashi et al., 2015). The sea surface temperature around the Teuri Island breeding colony increases during the breeding season from about $5^{\circ} \mathrm{C}$ in early April to $15^{\circ} \mathrm{C}$ in early July (Ito et al., 2009). Lower critical temperature (LCT) is typically higher on water than in air, and the rate of increase in metabolic rate as ambient temperature decreases below LCTis often steeper on water than in air (e.g. Stahel \& Nicol, 1982; Gabrielsen, Mehlum $\&$ Karlsen, 1988). Because auklets spend up to $55 \%$ of their time resting on the sea, it is important to determinine whether water temperature influences energy expenditure while resting. However, little is known about how much energy rhinoceros auklets require for thermoregulation while resting on water at various water temperatures.

In order to elucidate the energy cost of the time spent resting on the sea for pelagic seabirds, the resting metabolic rate (RMR) and daily energy expenditure (DEE) of the rhinoceros auklet were estimated quantitatively. RMR both in the air and on water, at various ambient temperatures, was measured using respirometry - the most common technique for measuring energy expenditure (Halsey, 2011). The DEE of rhinoceros auklets rearing chicks was estimated using the doubly labeled water (DLW) method - a common technique for estimating energy expenditure of freeliving animals (Shaffer, 2010). These data were then used to assess their LCT in air and on water, and the energy cost of resting on water as a proportion of their DEE while rearing chicks. 
88

89

90

91

92

93

94

95

96

97

98

99

100

101

102

103

104

105

106

107

108

109

110

111

112

113

114

115

116

117

118

119

120

121

122

123

124

125

126

127

128

129

130

131

132

133

\section{Materials \& Methods}

\section{Study area and species}

This study was carried out at Teuri Island $\left(44^{\circ} 25^{\prime} \mathrm{N}, 141^{\circ} 52^{\prime} \mathrm{E}\right)$, in the northern Sea of Japan, off northwest Hokkaido, from May to July 2015-2107. About 300,000 pairs of rhinoceros auklets breed on the island in the largest single breeding colony in the world (Watanuki \& Ito, 2012).

To measure the RMRs of adult auklets in air and on water using respirometry, 43 auklets were captured, using landing nets, as they returned to their nests at night. Individual birds were used for only one measurement of RMR in air or on water. Birds were captured and experimented upon under license from the Ministry of the Environment, Government of Japan.

During the chick-rearing period in 2017 specifically, 16 rhinoceros auklets were caught by hand or landing net at the nesting colony or in their nest burrows, five for measurements of background and initial isotope enrichment, and 11 for measurements of DEE by means of the DLW method.

The procedures used in this study were approved by the Animal Experimental Committee of Meijo University (2015-A-E-5, 2016-A-E-10, 2017-A-E-2). The fieldwork was permitted by the Ministry of the Environment (21-26-0291 0292, 21-27-0367 036803690370 0371, 21-28-0344 $035036037)$ and the Agency of Cultural Affairs (26-4-2188, 27-4-1928, 29-4-18).

Measurements of resting metabolic rate using respirometry in air and on water Oxygen consumption rate $\left(\mathrm{Vo}_{2}\right)$ was measured using an open-flow respirometry system composed of an acrylic metabolic chamber and an oxygen analyzer (Xentra 4100, Servomex Ltd, UK) as previously described in Shirai et al. (2015). For the measurement of RMR in air, a 20-L metabolic chamber $(20 \mathrm{~cm}$ long $\times 25 \mathrm{~cm}$ high $\times 40 \mathrm{~cm}$ wide) was submerged in a thermostatic water bath and maintained at $4.7-20.7^{\circ} \mathrm{C}$. For the measurement of RMR on water, a 72-L metabolic chamber (30 cm long $\times 60 \mathrm{~cm}$ high $\times 40 \mathrm{~cm}$ wide) was filled with freshwater (to a depth of $30 \mathrm{~cm}$ ) maintained at $5.5-17.5^{\circ} \mathrm{C}$.

The wild-caught auklets were placed in darkened boxes $(30 \mathrm{~cm} \times 30 \mathrm{~cm} \times 25 \mathrm{~cm})$, transported from the colony to the field station situated within 10 min of the capture site, then kept for at least one hour to minimize the effects of capture stress on their metabolic rates (Shirai et al., 2013). After one hour, they were weighed to the nearest $5 \mathrm{~g}$, using a Pesola spring balance. They were then placed in the metabolic chamber for 12 hours over night to measure their RMR. After finishing the measurements, they were weighed again and released on the colony at night. We assumed a linear decrease in body mass to estimate the body mass value used for calculating the mass-specific metabolic rate.

During measurements, the chamber was kept dark by covering it with a blackout curtain. The chamber temperature $\left(\mathrm{Tc}, \pm 0.3^{\circ} \mathrm{C}\right)$ and atmospheric pressure $(\mathrm{Pa}, \pm 1.5 \mathrm{hPa})$ were recorded (using a TR-73U Thermo Recorder T\&D Corp.), and water temperature was measured every minute $\left( \pm 0.3^{\circ} \mathrm{C}\right.$, using a TR-52i Thermo Recorder T\&D Corp.). The rate of airflow $\left(\mathrm{V}_{\mathrm{E}}\right)$ through the chamber was controlled at $2.0 \mathrm{Lmin}^{-1}$ in air and $3.0 \mathrm{Lmin}^{-1}$ on water using a mass flow controller ( $\pm 2 \%$, Type HM1171A, Tokyo Keiso). The effluent air from the chamber was dried and a fraction of the dry outlet air was directed into the oxygen analyzer. Absorption of oxygen into water in the chamber was less than $0.0015 \%$ per minute (Allers \& Culik, 1997). The oxygen analyzer was calibrated using dry effluent air $(20.946 \%$ oxygen) and pure stock nitrogen $(0.000 \%$ oxygen $)$ before beginning each experiment. The oxygen concentration of the effluent air $\left(\mathrm{F}_{\mathrm{EO} 2}\right)$ was recorded every minute by computer.

$\mathrm{Vo}_{2}$ was calculated using formula $3 \mathrm{~A}$ in Withers (1977) as follows, 


$$
V_{O 2}=\frac{V_{E} \times\left(F_{I O 2}-F_{E O 2}\right)}{1-(1-R Q) \times F_{I O 2}}
$$

RQ was the respiratory quotient, assumed to be 0.8 based on Koteja (1996). F $_{\text {IO2 }}$ was an oxygen concentration of influent air of $20.946 \%$. A conversion coefficient was used $20.1 \mathrm{kJL}^{-1}$ in calculating energy expenditure (Schmidt-Nielsen, 1997). All results are given at standard temperature, pressure, and dryness (STPD).

As previously described in Shirai et al. (2013), we estimated RMR to be the minimum value recorded over a 20 min interval during the $12 \mathrm{~h}$ measurements (Supplemental Table 1). method as previously described in Niizuma \& Shirai (2015). The method allowed an estimation of initial isotope enrichment from a single blood sample and was a less invasive technique with lower impact on the behavior of study subjects (Schultner et al., 2010; Niizuma \& Shirai, 2015). Recent validation studies have demonstrated that the precision of the DLW technique can be increased by using a longer sampling interval and/or by applying it to a species with a higher metabolic rate (Shirai et al., 2015; Kume et al., 2019). The DLW injectate used in our study contained 21.0 atom percent ${ }^{18} \mathrm{O}, 10.5$ atom percent ${ }^{2} \mathrm{H}$, and $0.9 \% \mathrm{NaCl}$.

Blood samples from five wild-caught auklets taken between 21:00-22:00 were used to determine mean background and initial levels of the ${ }^{2} \mathrm{H}$ and ${ }^{18} \mathrm{O}$ isotopes. After capturing the birds, $1 \mathrm{~mL}$ of blood was collected from the brachial vein as a background sample; then the DLW was injected into the body cavity. After the DLW injection, the auklets were kept individually in plastic boxes for 90 minutes; then further 1-mL blood samples were collected from each individual as initial samples. After sampling, they were weighed with a Pesola spring balance accurate to the nearest $10 \mathrm{~g}$; then released at the nesting site.

Eleven individuals were caught in their nest burrows with their chicks to investigate their DEE. DLW was injected into the abdominal cavity of each bird. After being weighed, all individuals were banded with individually numbered metal bands and released back into their nests. Four of the injected individuals were recaptured in their nest burrows at night after they had returned from foraging trips. Immediately after recapture, a final 1-mL blood sample was collected, and each bird was re-weighed. These procedures were conducted at night (21:00-23:00) to mitigate breeding disturbance (Sun et al., 2020), and required less effort for recapturing birds when compared with previous studies involving attaching bird-borne data-loggers (Kuroki et al., 2003; Kato, Watanuki \& Naito, 2003; Matsumoto et al., 2008). Therefore, the recovery rate in this study was relatively lower than in previous ones.

We quantified the injectate by weighing the syringe (to the nearest $0.0001 \mathrm{~g}$ with an electronic balance in the field laboratory) before and after each injection following Speakman (1997). On average, birds were injected with 3.1326 g DLW ( \pm 0.0783 s.d.). We heparinized and centrifuged (5 min, $6200 \mathrm{rpm}$ ) all blood samples. After centrifugation, we stored each serum sample at $-25^{\circ} \mathrm{C}$ in a $0.5 \mathrm{~mL}$ screw-topped plastic vial with an O-ring (Asahi Techno Glass Co.) until isotopic analysis.

We diluted the serum and injectate samples with distilled water measured with an electronic balance (Mettler-Toledo, Columbus, OH, USA) to the nearest $0.01 \mathrm{mg}$. We analyzed the ${ }^{2} \mathrm{H}$ and ${ }^{18} \mathrm{O}$ isotope concentrations of the serum, DLW injectate, and distilled water using isotope ratio mass spectrometry (IRMS; Hydra 20-20, Sercon, Crewe, UK; Shirai et al., 2012, 2015). We used the water equilibration method (Horita et al., 1989) to analyze the serum, DLW injectate, and 
179 distilled water in duplicate. Water standards (Iso-Analytical, Crewe, UK) were used to establish 180 calibration curves for normalizing the values. Each sample was analyzed in duplicate. All isotope 181 enrichments were measured in $\delta$ per mille relative to the working standards and converted to an absolute ratio for ${ }^{2} \mathrm{H}$ by using equation 14.4 , and for ${ }^{18} \mathrm{O}$ by using equation 14.9, from Speakman (1997). Absolute ratios were converted to ppm using equations from Speakman (1997): equation 18414.8 for ${ }^{2} \mathrm{H}$, and equation 14.14 for ${ }^{18} \mathrm{O}$. All subsequent calculations in the DLW method were performed on the mean values of each sample analyzed in duplicate.

Ideally, background and initial isotope levels should be determined for each subject (Speakman \& Racey, 1987). However, since this increases both the handling time and disturbance of the subject, the background and initial isotope abundances were determined for just five individuals. The background isotope level averaged $2002.04 \mathrm{ppm}$ (range $1999.75-2005.16 \mathrm{ppm}$ ) for ${ }^{18} \mathrm{O}$ and 159.64 ppm (range 156.22-165.77 ppm) for ${ }^{2} \mathrm{H}$. We used these mean background levels to calculate the $\mathrm{CO}_{2}$ production rate $\left(\mathrm{rCO}_{2}, \mathrm{~mL}_{\text {day }}{ }^{-1}\right)$.

We also estimated initial isotope enrichment based on the relationship of increments for isotope injection $\left(\mathrm{H}_{\text {inc }}\right.$ or $\left.\mathrm{O}_{\text {inc }}, \mathrm{ppm}\right)$ and body mass $(\mathrm{BM}, \mathrm{g})$ and respective DLW injectate established for the birds as previously described in Niizuma \& Shirai (2015).

$$
\begin{aligned}
& H_{i n c}=-1915.0+3.835 \times B M+17661.0 \times H_{i n j}-27.141 \times B M \times H_{i n j}, \\
& H_{i}=H_{i n c}+H_{b}, \\
& O_{i n c}=-3875.7+8.639 \times B M+36186.2 \times O_{i n j}-60.213 B M \times O_{i n j,}, \\
& O_{i}=O_{i n c}+O_{b},
\end{aligned}
$$

where $H_{i n j}$ and $O_{i n j}$ represent the respective DLW injectate $\left({ }^{2} \mathrm{H}\right.$ or $\left.{ }^{18} \mathrm{O}, \mathrm{mol}\right), H_{i}$ and $O_{i}$ represent the estimated initial isotope enrichments and $H_{b}$ and $O_{b}$ represent the background isotope enrichments $\left({ }^{2} \mathrm{H}\right.$ or ${ }^{18} \mathrm{O}$, ppm). The $H_{\text {inc }}$ equation has an adjusted $\mathrm{R}^{2}$ of 0.942 , while the $O_{i n c}$ equation has an adjusted $\mathrm{R}^{2}$ of 0.952 .

Using the DLW injectates, the background and the estimated initial isotope enrichments, we calculated the isotope dilution spaces for ${ }^{18} \mathrm{O}\left(N_{o}, \mathrm{~mol}\right)$ using the general equation:

$$
N_{o}=\frac{O_{i n j} \times\left(O_{i}-O_{d}\right)}{O_{b}-O_{i}}
$$

208

209

210

211

212

213

214

215

216

217

218

219

where $O_{d}$ represents the isotope concentration $\left({ }^{2} \mathrm{H}\right.$ or ${ }^{18} \mathrm{O}$, ppm) in the DLW injectate. To convert the units of the isotope dilution spaces, we used a conversion factor of $18.002 \mathrm{~g} \mathrm{~mol}^{-1}$ (Speakman 1997).

The turnover rates for ${ }^{2} \mathrm{H}$ and ${ }^{18} \mathrm{O}\left(k_{d}\right.$ and $k_{o}$, respectively, day $\left.{ }^{-1}\right)$ were determined using the following general equations:

$$
\begin{gathered}
k_{d}=\frac{\ln \left(H_{i}-H_{b}\right)-\ln \left(H_{f}-H_{b}\right)}{t} \\
k_{o}=\frac{\ln \left(O_{i}-O_{b}\right)-\ln \left(O_{f}-O_{b}\right)}{t}
\end{gathered}
$$

where $H_{f}$ and $O_{f}$ represent the respective isotope concentrations $\left({ }^{2} \mathrm{H}\right.$ or ${ }^{18} \mathrm{O}$, ppm) of the final samples and $t$ represents the time interval between the injection and final samples (days; Lifson and McClintock 1966; (Speakman, 1997).

As previously described in Shirai et al. (2012a), we used Speakman's (1997) one-pool model for calculating $\mathrm{rCO} 2$ in this study as follows: 


$$
r C O_{2}=\frac{N}{2.078}\left(k_{o}-k_{d}\right)-0.0062 \times k_{d} \times N
$$

221

222

223

224

225

226

227

228

229

230

231

232

233

234

235

236

237

238

239

240

241

242

243

244

245

246

247

248

249

250

251

252

253

254

255

256

257

258

259

260

261

262

263

where $N=N_{o}$. To convert units in $\mathrm{mLCO}_{2}$ day $^{-1}$ into energy equivalents, it was assumed that 1 $\mathrm{mL}$ of $\mathrm{CO}_{2}$ equals 25.11 J (Gessaman \& Nagy, 1988).

\section{Statistical analysis}

All statistical analyses were performed in R 3.3.2 (R Development Core Team 2016). Massspecific metabolic rates of rhinoceros auklets resting in air and on water were tested for mean differences among air and water temperatures using one-way analysis of variance (ANOVA). When significant differences were observed among temperatures, the Tukey-Kramer multiplecomparison test was applied to determine which means were significantly different.

\section{Results}

Measurements of Resting Metabolic Rate in air and on water

The RMR of rhinoceros auklets (555.6 $\mathrm{g} \pm 39.6$ s.d., $\mathrm{n}=27)$ in air was not affected by air temperature $\left(F_{3,23}=0.893, P=0.460\right.$; Figure 1a). The RMR in air averaged $0.0258 \pm 0.0033 \mathrm{~kJ}$ $\mathrm{g}^{-1} \mathrm{~h}^{-1}(\mathrm{n}=27)$.

The RMR of the auklets $(565.6 \pm 48.7 \mathrm{~g}, \mathrm{n}=16)$ on water was affected significantly by water temperature $\left(F_{2,13}=8.32, P=0.0047\right.$; Figure $\left.1 \mathrm{~b}\right)$. While RMR on water did not vary significantly between $10^{\circ} \mathrm{C}\left(0.0366 \pm 0.0045 \mathrm{~kJ} \mathrm{~g}^{-1} \mathrm{~h}^{-1}, \mathrm{n}=5\right)$ and $15^{\circ} \mathrm{C}\left(0.0347 \pm 0.0036 \mathrm{~kJ} \mathrm{~g}^{-1} \mathrm{~h}^{-1}, \mathrm{n}=6\right)\left(t_{14}\right.$ $=0.686, P=0.780)$, it was significantly higher at $5^{\circ} \mathrm{C}\left(0.0460 \pm 0.0060 \mathrm{~kJ} \mathrm{~kg}^{-1} \mathrm{~h}^{-1}, \mathrm{n}=5\right)(5 \mathrm{vs}$ $15^{\circ} \mathrm{C}: t_{14}=3.894, P=0.0049 ; 5$ vs $\left.10^{\circ} \mathrm{C}: t_{14}=3.071, P=0.0226\right)$. Auklet RMR on water at combined temperatures of $10^{\circ} \mathrm{C}$ and $15^{\circ} \mathrm{C}$ was $0.0356 \pm 0.0040 \mathrm{~kJ} \mathrm{~g}^{-1} \mathrm{~h}^{-1}, \mathrm{n}=11$ ).

Daily Energy Expenditure of chick-rearing Rhinoceros Auklets

Four birds were recaptured after foraging trips following DLW injection. Three were recaptured after one-day trips $(24.1 \pm 0.3$ hours), but one was recaptured after a three-day ( 72.5 hours) trip and was found to have almost equal the final isotopic enrichment to the background abundance. Therefore, calculations of DEE were only possible for three individuals. The DEE of free-ranging auklets, which initially weighed $556.3 \mathrm{~g}( \pm 42.0, \mathrm{n}=3)$, averaged $1005.5 \mathrm{kJday}^{-1}( \pm 130.2, \mathrm{n}=3)$. The DEE/RMR ratio (based on RMR in air) was 2.9.

\section{Discussion}

Air temperature was not found to affect adult rhinoceros auklet RMR over the range of temperatures measured. However, when RMRs were measured for adult rhinoceros auklets on water, there was an effect of temperature, with an increase in RMR at the lowest temperature (Figure 1). Our measurements of RMR in air are similar to the $0.0248 \mathrm{~kJ} \mathrm{~g}^{-1} \mathrm{~h}^{-1}$ for basal metabolic rate (BMR; Shirai et al., 2013) and the value estimated from the allometric equation for the Charadriiformes $\left(0.0259 \mathrm{~kJ} \mathrm{~g}^{-1} \mathrm{~h}^{-1} ; \mathrm{BMR}=2.149 \mathrm{~m}^{0.804} \mathrm{~kJ} /\right.$ day, where $\mathrm{m}$ is body mass (556 g); (Ellis \& Gabrielsen, 2002). Nonetheless, we acknowledge that capture may cause a stress response whereby birds subsequently spend considerable time preening on the water leading to a low DEE (Schultner et al., 2010), especially for auklets, which are known to be particularly sensitive to disturbance (Sun et al., 2020) as shown by our low recapture rate. The DEE was equal to $112 \%$ and within the confidence interval $\left(577-1276 \mathrm{kJday}^{-1}\right)$ of the predicted DEE that was calculated (using latitude $=44^{\circ}$, body mass $=556 \mathrm{~g}$, and breeding phase $=$ Brood) 
264 from an allometric equation for seabirds (Dunn, White \& Green, 2018). This suggests that the

265

266

267

268

269

270

271

272

273

274

275

276

277

278

279

280

281

282

283

284

285

286

287

288

289

290

291

292

293

294

295

296

297

298

299

300

301

302

303

304

305

306

307

308

309

measured DEE of rhinoceros auklets is reasonable in comparison with previous seabird studies.

\section{Resting metabolic rate in air and on water}

We were unable to demonstrate the existence of an LCT in air for rhinoceros auklets in this study, but suspect it to be at least lower than $5^{\circ} \mathrm{C}$. The LCT in air of seabirds decreases with body mass and latitude. Although the LCT for adult rhinoceros auklets on Teuri Island was estimated to be $13.6^{\circ} \mathrm{C}$ from equation 11.9 in Ellis \& Gabrielsen (2002), our results suggest that it is lower than the estimation. The LCT of rhinoceros auklets in air is similar to that of other seabird species such as common murre (Uria aalge), thick-billed murre (U. lomvia), dovekie (Alle alle), black guillemot (Cepphus grylle) and black-legged kittiwake (Rissa tridactyla) that breed in arctic regions (Johnson \& West, 1975; Gabrielsen, Mehlum \& Karlsen, 1988; Gabrielsen et al., 1991), but not northern fulmar (Fulmarus glacialis) which has an LCT in air of $9.0^{\circ} \mathrm{C}$ (Gabrielsen, Mehlum \& Karlsen, 1988). Cassin's auklet breeding on Triangle Island, British Columbia, Canada (N 50 $)$, had an LCT in air of $16^{\circ} \mathrm{C}$ (Richman \& Lovvorn, 2011) which is higher than that of the rhinoceros auklet. Despite breeding in the temperate zone, the rhinoceros auklets in this study had similar thermal properties at LCT in air to those breeding in the Arctic. Their insulation properties would constrain their heat dissipation rate during flapping flight between their nesting and foraging areas, especially in the temperate zone (Guillemette et al., 2016; Nord \& Nilsson, 2019). Alcidae are noted to have an energy expenditure that is 31 times greater than BMR during flight, which is the highest known for any vertebrate (Elliott et al., 2013a). Since Teuri Island is at the southern limit of this species' breeding area in the west Pacific, rhinoceros auklets with a lower LCT in air would have difficulty in dissipating heat while flying with food from their foraging area to their nesting site due to their high level of insulation in air (Schraft, Whelan \& Elliott, 2019).

In contrast to their RMR in air, we estimated the LCT on water of rhinoceros auklets between $5^{\circ} \mathrm{C}$ and $10^{\circ} \mathrm{C}$. Their LCT on water is lower than that for common murre, thick-billed murre and Cassin's auklet (Croll \& McLaren, 1993; Richman \& Lovvorn, 2011). This result could have important implications for their ecology. The sea surface temperature around Teuri Island increases from about $5^{\circ} \mathrm{C}$ in early April to $15^{\circ} \mathrm{C}$ in early July during the auklet breeding season (Ito et al., 2009). After breeding, the auklets migrate to more southerly areas where, from October to late February, they experience water temperatures of $11-14^{\circ} \mathrm{C}$, but for a short period from early March to April associated with their northward migration they experience sea surface temperatures of $4-6^{\circ} \mathrm{C}$ (Takahashi et al., 2015). Therefore, they could rest on the sea at minimum energetic cost during most seasons due to their LCT on water being lower than the usual sea surface temperature. However, foraging auklets may remain longer on the sea after diving to digest their food (Elliott et al., 2014) and thus increase their metabolic rate for the obligatory component of the heat increment of feeding (Hawkins et al., 1997), which may be used for thermoregulation on water.

\section{The Energetic cost of resting on the sea surface}

The DEE/RMR ratio provides an estimate of how much birds must increase baseline costs to forage and thermoregulate in a particular environment and may be intrinsically set by physiological constraints (within four times RMR in air) (Drent \& Daan, 1980). The value in this study is below the proposed 'energetic ceiling' level and within the range among Alcidae (2.73.8 reviewed in Ellis \& Gabrielsen, 2002).

Since the sea surface temperature around Teuri Island during the chick-rearing period was 8 $13^{\circ} \mathrm{C}$ (Ito et al., 2009), the auklets can be assumed to expend their energy within their TLC while

PeerJ reviewing PDF | (2020:09:52974:4:0:NEW 23 Apr 2021) 
310 resting on the water around the breeding site. For rhinoceros auklets, the energy cost of resting 311 on water is likely to be dependent on the time spent on water per day (\%). Rhinoceros auklets 312 spend up to $55 \%$ of their time on water (Kato, Watanuki \& Naito, 2003) because they only 313 deliver food to their chick once a day at most (Watanuki, 1987; Takahashi et al., 1999). Common 314 murres at Witless Bay, Newfoundland spend longer resting on water (57.5\% of their time) 315 (Cairns et al., 1990) than those at Hornøya (24.9\%) (Tremblay et al., 2003). When capelin 316 (Mallotus villosus) are present, common murres at Witless Bay have access to abundant food and 317 can forage within $10 \mathrm{~km}$ of their colony (Regular, Hedd \& Montevecchi, 2013). Time on water 318 per day (\%) may also vary with food abundance for the rhinoceros auklet. Although we did not

319

320

321

322

323

324

325

326

327

328

329

330

331

332

333

334

335

336

337

338

339

340

341

342

343

344

345

346

347

348

349

350

351

352

353

354 measure time spent on water per day $(\%)$ for the same individual auklets for which we measured DEE, their energy expenditure while resting on the sea was estimated to be $261.4 \mathrm{kJday}^{-1}$, or $26.0 \%$ of the DEE if they spent the same time resting on the sea within their LCT as in the previous study (Kato, Watanuki \& Naito, 2003).

\section{Conclusions}

Many studies of seabird energetics have concentrated on quantifying the energetics of flying and diving because such locomotion is considered costly (Elliott et al., 2013b). However, seabirds spend considerable amounts of their time at all seasons resting on the sea. In this study, we have shown that the RMR of resting auklets is elevated, particularly at temperatures below their LCT on water, compared with in air. Accordingly, spending time above their LCT on water provides enhanced benefits, particularly to seabirds such as rhinoceros auklets which rest for a considerable amount of time on water each day.

\section{Acknowledgements}

We are grateful to M. Aotsuka, Y. Watanuki, M. Yamamoto, S. Hashimoto, A. Takahashi, N. Sato and U. Shimabukuro M. We would also like to thank M. Brazil, Scientific Editing Services, for help with the preparation of the final manuscript and Dr. K. Welch Jr, Dr. K. Elliot, Dr. J. A. Green and an anonymous referee for their many comments for improvements to this manuscript. Part of the work was supported by the Co-operation Research Program of the Wildlife Research Centre, Kyoto University.

\section{References}

Allers D, Culik BM. 1997. Energy requirements of beavers (Castor canadensis) swimming underwater. Physiological Zoology 70:456-463. DOI: 10.1086/515852.

Cairns DK, Montevecchi WA, Birt-Friesen VL, Macko SA. 1990. Energy expenditures, activity budgets, and prey harvest of breding common murres. Studies in Avian Biology 14:84-92.

Croll DA, McLaren E. 1993. Diving metabolism and thermoregulation in common and thickbilled murres. Journal of Comparative Physiology B 163:160-166. DOI: 10.1007/BF00263602.

Daunt F, Benvenuti S, Harris M, Dall'Antonia L, Elston D, Wanless S. 2002. Foraging strategies of the black-legged kittiwake Rissa tridactyla at a North Sea colony: evidence for a maximum foraging range. Marine Ecology Progress Series 245:239-247. DOI: $10.3354 /$ meps 245239 .

Dawson C, Vincent JF., Jeronimidis G, Rice G, Forshaw P. 1999. Heat Transfer through Penguin Feathers. Journal of Theoretical Biology 199:291-295. DOI: 10.1006/JTBI.1999.0959. 
355

356

357

358

359

360

361

362

363

364

365

366

367

368

369

370

371

372

373

374

375

376

377

378

379

380

381

382

383

384

385

386

387

388

389

390

391

392

393

394

395

396

397

398

Drent S, Daan RH. 1980. The prudent parent: energetic adjustments in avian breeding. Ardea 68:225-252.

Dunn RE, White CR, Green JA. 2018. A model to estimate seabird field metabolic rates. Biology Letters 14:20180190. DOI: 10.1098/rsbl.2018.0190.

Elliott KH, Ricklefs RE, Gaston AJ, Hatch SA, Speakman JR, Davoren GK. 2013a. High flight costs, but low dive costs, in auks support the biomechanical hypothesis for flightlessness in penguins. Proceedings of the National Academy of Sciences of the United States of America 110:9380-9384. DOI: 10.1073/pnas.1304838110.

Elliott KH, Le Vaillant M, Kato A, Gaston AJ, Ropert-Coudert Y, Hare JF, Speakman JR, Croll D. 2014. Age-related variation in energy expenditure in a long-lived bird within the envelope of an energy ceiling. Journal of Animal Ecology 83:136-146. DOI: 10.1111/13652656.12126.

Elliott KH, Le Vaillant M, Kato A, Speakman JR, Ropert-Coudert Y. 2013b. Accelerometry predicts daily energy expenditure in a bird with high activity levels. . Biology letters 9:20120919.

Ellis HI, Gabrielsen GW. 2002. Energetics of free-ranging seabirds. In: Schreiber EA, Burger J eds. Biology of marine birds. Boca Raton.: CRC Press, 359-07.

Falk K, Benvenuti S, Dall'Antonia L, Kampp K, Ribolini A. 2000. Time allocation and foraging behaviour of chick-rearing Brunnich's Gullemots Uria lomvia in high-arctic Greenland. Ibis 142:82-92.

Folkow L. P, Blix AS. 1987. Nasal heat and water exchanges in gray seals. Am. J. Physiol. 253:R883-R889.

Gabrielsen GW, Mehlum F, Karlsen HE. 1988. Thermoregulation in four species of arctic seabirds. Journal of Comparative Physiology B 157:703-708. DOI: 10.1007/BF00691000.

Gabrielsen GW, Taylor JRE, Konarzawski M, Mehlum F. 1991. Field and laboratory metabolism and thermoregulation in dovekies (Alle alle). Auk 108:71-78.

Garthe S, Grémillet D, Furness R. 1999. At-sea-activity and foraging efficiency in chick-rearing northern gannets Sula bassana:a case study in Shetland. Marine Ecology Progress Series 185:93-99. DOI: 10.3354/meps185093.

Gaston AJ (Anthony J., Jones IL. 1998. The auks: Alcidae. Oxford: Oxford University Press.

Gessaman JA, Nagy KA. 1988. Energy Metabolism: Errors in Gas-Exchange Conversion Factors. Physiological Zoology 61:507-513. DOI: 10.1086/physzool.61.6.30156159.

Guillemette M, Woakes AJ, Larochelle J, Polymeropoulos ET, Granbois JM, Butler PJ, Pelletier D, Frappell PB, Portugal SJ. 2016. Does hyperthermia constrain flight duration in a shortdistance migrant? Philosophical Transactions of the Royal Society B: Biological Sciences 371. DOI: $10.1098 /$ rstb.2015.0386.

Halsey LG. 2011. The challenge of measuring energy expenditure: Current field and laboratory methods. . Comparative Biochemistry and Physiology, Part A 158:247-251.

Hawkins P, Butler P, Woakes A, Gabrielsen G. 1997. Heat increment of feeding in Brunnich's guillemot. Journal of Experimental Biology 200.

Horita J, Ueda A, Mizukami K, Takatori I. 1989. Automatic $\delta \mathrm{D}$ and $\delta 180$ analyses of multiwater samples using $\mathrm{H} 2$ - and $\mathrm{CO} 2$-water equilibration methods with a common equilibration set-up. International Journal of Radiation Applications and Instrumentation. Part 40:801-805. DOI: 10.1016/0883-2889(89)90100-7. 
399

400

401

402

403

404

405

406

407

408

409

410

411

412

413

414

415

416

417

418

419

420

421

422

423

424

425

426

427

428

429

430

431

432

433

434

435

436

437

438

439

440

441

442

443

444

Humphreys EM, Wanless S, Bryant DM. 2006. Elevated metabolic costs while resting on water in a surface feeder: the Black-legged Kittiwake Rissa tridactyla. Ibis 149:106-111. DOI: 10.1111/j.1474-919X.2006.00618.x.

Ito M, Minami H, Tanaka Y, Watanuki Y. 2009. Seasonal and inter-annual oceanographic changes induce diet switching in a piscivorous seabird. Marine Ecology Progress Series 393:273-284. DOI: 10.3354/meps08192.

Jenssen BM, Ekker M, Bech C. 1989. Thermoregulation in winter-acclimatized common eiders ( Somateria mollissima ) in air and water. Canadian Journal of Zoology 67:669-673. DOI: 10.1139/z89-096.

Johansen K, Bech C. 1983. Heat conservation during cold exposure in birds (vasomotor ans respiratory implications). Polar Research 1:259-268.

Johnson SR, West GC. 1975. Growth and Development of Heat Regulation in Nestlings, and Metabolism of Adult Common and Thick-Billed Murres. Ornis Scandinavica 6:109-115. DOI: $10.2307 / 3676282$.

Kaseloo PA, Lovvorn JR. 2005. Effects of surface activity patterns and dive depth on thermal substitution in fasted and fed lesser scaup (Aythya affinis) ducks. Can. J. Zool. 83:301-311.

Kato A, Watanuki Y, Naito Y. 2003. Foraging behaviour of chick-rearing rhinoceros auklets Cerorhinca monocerata at Teuri Island, Japan, determined by acceleration-depth recording micro data loggers. Journal of Avian Biology 34:282-287. DOI: 10.1034/j.1600048X.2003.03134.x.

Kooyman GL, Gentry RL, Bergman WP, Hammel HT. 1976. Heat loss in penguins during immersion and compression. Comp. Biochem. Physiol. 54A:75-80.

Koteja P. 1996. Measuring Energy Metabolism with Open-Flow Respirometric Systems: Which Design to Choose? Functional Ecology 10:675. DOI: 10.2307/2390179.

Kume Y, Shirai M, Mizutani Y, Niizuma Y. 2019. Parental birds incubating larger clutches regulate their field metabolic rates in response to environmental changes. Ornithological Science 18:161-167. DOI: 10.2326/OSJ.18.161.

Kuroki M, Kato A, Watanuki Y, Niizuma Y, Takahashi A, Naito Y. 2003. Diving behavior of an epipelagically feeding alcid, the Rhinoceros Auklet (Cerorhinca monocerata). Canadian Journal of Zoology 81:1249-1256. DOI: 10.1139/z03-112.

Lovvorn JR, Grebmeier JM, Cooper LW, Bump JK, Richman SE. 2009. Modeling Marine Protected Areas for Threatened Eiders in a Climatically Changing Bering Sea. Ecological Applications 19:1596-1613. DOI: 10.2307/40346272.

Matsumoto K, Deguchi T, Wada A, Kato A, Saitoh S, Watanuki Y. 2008. Estimating foraging area of Rhinoceros Auklets by simultaneous sampling of water temperature profiles using bird-borne data-loggers. Ornithological Science 7:37-46. DOI: 10.2326/13470558(2008)7[37:efaora]2.0.co;2.

Niizuma Y, Gabrielsen GW, Sato K, Watanuki Y, Naito Y. 2007. Brünnich's guillemots (Uria lomvia) maintain high temperature in the body core during dives. Comparative Biochemistry and Physiology Part A: Molecular \& Integrative Physiology 147:438-444. DOI: 10.1016/J.CBPA.2007.01.014.

Niizuma Y, Shirai M. 2015. Applicability of a Single-Sample Approach for the Doubly Labelled Water Method to the Streaked Shearwater Calonectris leucomelas. Ornithological Science 14:21-28. DOI: 10.2326/osj.14.21.

Nilsson J-Å, Molokwu MN, Olsson O. 2016. Body Temperature Regulation in Hot Environments. PLOS ONE 11:e0161481. DOI: 10.1371/journal.pone.0161481. 
445

446

447

448

449

450

451

452

453

454

455

456

457

458

459

460

461

462

463

464

465

466

467

468

469

470

471

472

473

474

475

476

477

478

479

480

481

482

483

484

485

486

487

488

489

Nord A, Nilsson J. 2019. Heat dissipation rate constrains reproductive investment in a wild bird. Functional Ecology 33:250-259. DOI: 10.1111/1365-2435.13243.

Regular PM, Hedd A, Montevecchi WA. 2013. Must marine predators always follow scaling laws? Memory guides the foraging decisions of a pursuit-diving seabird. Animal Behaviour 86:545-552. DOI: 10.1016/j.anbehav.2013.06.008.

Richman SE, Lovvorn JR. 2011. Effects of air and water temperatures on resting metabolism of auklets and other diving birds. Physiological and biochemical zoology 84:316-332. DOI: $10.1086 / 660008$.

Schmidt-Nielsen K. 1997. Animal physiology: adaptation and environment. Cambridge: Cambridge University Press.

Schraft HA, Whelan S, Elliott KH. 2019. Huffin' and puffin: Seabirds use large bills to dissipate heat from energetically demanding flight. Journal of Experimental Biology 222. DOI: 10.1242/jeb.212563.

Schultner J, Welcker J, Speakman JR, Nordoy ES, Gabrielsen GW. 2010. Application of the two-sample doubly labelled water method alters behaviour and affects estimates of energy expenditure in black-legged kittiwakes. Journal of Experimental Biology 213:2958-2966. DOI: $10.1242 /$ jeb.043414.

Shaffer SA. 2010. A review of seabird energetics using the doubly labeled water method. Comp. Biochem. Physiol. A.

Shirai M, Ito M, Yoda K, Niizuma Y. 2013. Basal metabolic rate of the Rhinoceros Auklet Cerorhinca monocerata, as measured using respirometry. Marine Ornithology 41:151-153.

Shirai M, Niizuma Y, Yamamoto M, Oda E, Ebine N, Oka N, Yoda K. 2015. High levels of isotope elimination improve precision and allow individual-based measurements of metabolic rates in animals using the doubly labeled water method. Physiological Reports 3:1-15. DOI: 10.14814/phy2.12552.

Shirai M, Yamamoto M, Ebine N, Yamamoto T, Trathan PN, Yoda K, Oka N, Niizuma Y. 2012. Basal and Field Metabolic Rates of Streaked Shearwater During the Chick-Rearing Period. Ornithological Science 11:47-55. DOI: 10.2326/osj.11.47.

Speakman JR. 1997. Doubly labelled water: theory and practice. London: Chapman \& Hall Ltd.

Speakman JR, Król E. 2010. Maximal heat dissipation capacity and hyperthermia risk: neglected key factors in the ecology of endotherms. Journal of Animal Ecology 79:no-no. DOI: 10.1111/j.1365-2656.2010.01689.x.

Speakman JR, Racey PA. 1987. The equilibrium concentration of oxygen-18 in body water: Implications for the accuracy of the doubly-labelled water technique and a potential new method of measuring RQ in free-living animals. Journal of Theoretical Biology 127:79-95. DOI: $10.1016 / \mathrm{S} 0022-5193(87) 80162-5$.

Stahel CD, Nicol SC. 1982. Temperature regulation in the little penguin, Eudyptula minor, in air and water. Journal of Comparative Physiology B 148:93-100. DOI: 10.1007/BF00688892.

Sun A, Whelan S, Hatch S, Elliott K. 2020. Tags below three percent of body mass increase nest abandonment by rhinoceros auklets, but handling impacts decline as breeding progresses. Marine Ecology Progress Series 643:173-181. DOI: 10.3354/meps13341.

Takahashi A, Ito M, Suzuki Y, Watanuki Y, Thiebot JB, Yamamoto T, Iida T, Trathan P, Niizuma Y, Kuwae T. 2015. Migratory movements of rhinoceros auklets in the northwestern Pacific: Connecting seasonal productivities. Marine Ecology Progress Series 525:229-243. DOI: 10.3354/meps11179. 
490

491

492

493

494

495

496

497

498

499

500

501

502

503

504

Takahashi A, Kuroki M, Niizuma Y, Watanuki Y. 1999. Parental Food Provisioning Is Unrelated to Manipulated Offspring Food Demand in a Nocturnal Single-Provisioning Alcid, the Rhinoceros Auklet. Journal of Avian Biology 30:486. DOI: 10.2307/3677021.

Tremblay Y, Cherel Y, Oremus M, Tveraa T, Chastel O. 2003. Unconventional ventral attachment of time-depth recorders as a new method for investigating time budget and diving behaviour of seabirds. The Journal of Experimental Biology 206:1929-1940. DOI: 10.1242/jeb.00363.

Watanuki Y. 1987. Breeding biology and foods of Rhinoceros Auklets on Teuri Island, Japan. Proceedings of the NIPR Symposium on Polar Biology:175-183.

Watanuki Y, Ito M. 2012. Climatic effects on breeding seabirds of the northern Japan Sea. Marine Ecology Progress Series 454:183-196. DOI: 10.3354/meps09627.

Wilson RP, Weimerskirch H, Lys P. 1995. A Device for Measuring Seabird Activity at Sea. Journal of Avian Biology 26:172. DOI: 10.2307/3677067.

Withers PC. 1977. Measurement of Vo, Vco, and evaporative water loss with a flow-through mask. J. Appl. Physiol. Respirant. Environ. Exercise Physiol. 42:120-123. 
Figure 1

Figure 1. Resting metabolic rate (a) in air and (b) on water at different ambient temperatures in rhinoceros auklets.

Figure 1. Resting metabolic rate (a) in air and (b) on water at different ambient temperatures in rhinoceros auklets.
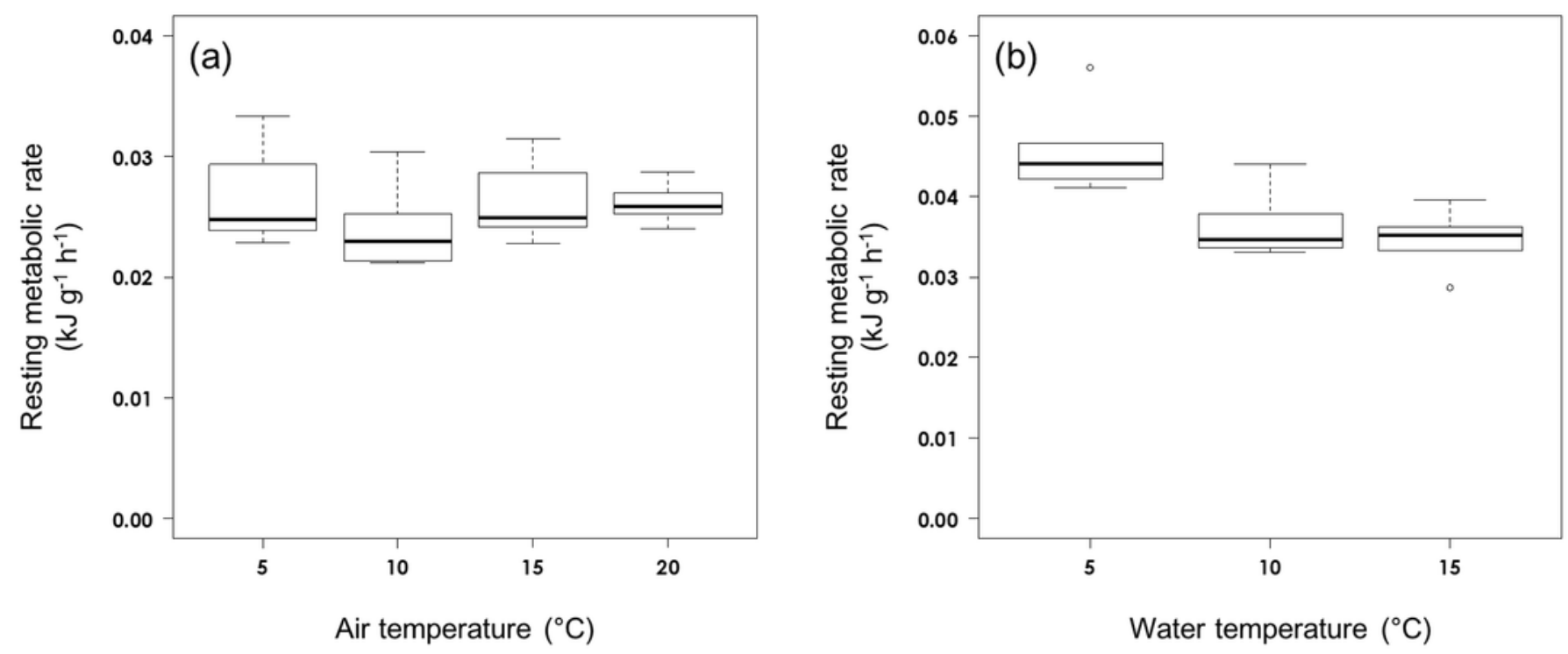